\title{
Liberal senators assail consumer safety bill
}

Published at www.cmaj.ca on Dec. 9, 2009

$\mathrm{T}$ he federal government's new consumer safety legislation is a step closer to becoming law after Liberal amendments designed to check the powers of Health Canada inspectors were defeated in the Senate.

The Senate voted 44-42 on Dec. 9, 2009, to pass Bill C-6, the Canada Consumer Product Safety Act, as originally drafted. The bill, which passed unanimously in the House of Commons in June 2009, updates aspects of the Food and Drug Act and the Hazardous Products Act (CMAJ 2009; DOI:10.1503 /cmaj.090239). It proposes giving Health Canada mandatory recall powers in cases of products deemed dangerous, such as the baby cribs with an adjustable side that Richmond, British Columbiabased Stork Craft Manufacturing Inc. recently recalled on a voluntary basis.

A final vote in the Senate after third reading of the bill was scheduled for Dec. 10, 2009. Roadblocks to passage of the legislation emerged when interest groups, private citizens and constitutional experts challenged the broad powers the legislation awards inspectors to enter premises without a warrant, seize products and hold them indefinitely. The Senate Social Affairs, Science and Technology Committee subsequently voted to amend the bill.

"What we're dealing with is an update of existing legislation, but it's an entirely new scheme that is being proposed, giving the government an awful lot more authority," says Liberal Senator Joseph Day, who proposed more than 20 amendments. "I wanted a check on that power."

In response, Health Minister Leona Aglukkaq, flanked by Conservative Senator Nicole Eaton and representatives from Safe Kids Canada and Options Consommateurs, put pressure on the Senate to pass the bill as originally introduced, accusing the Liberal senators of "gutting" the bill and putting Canadian children at risk.

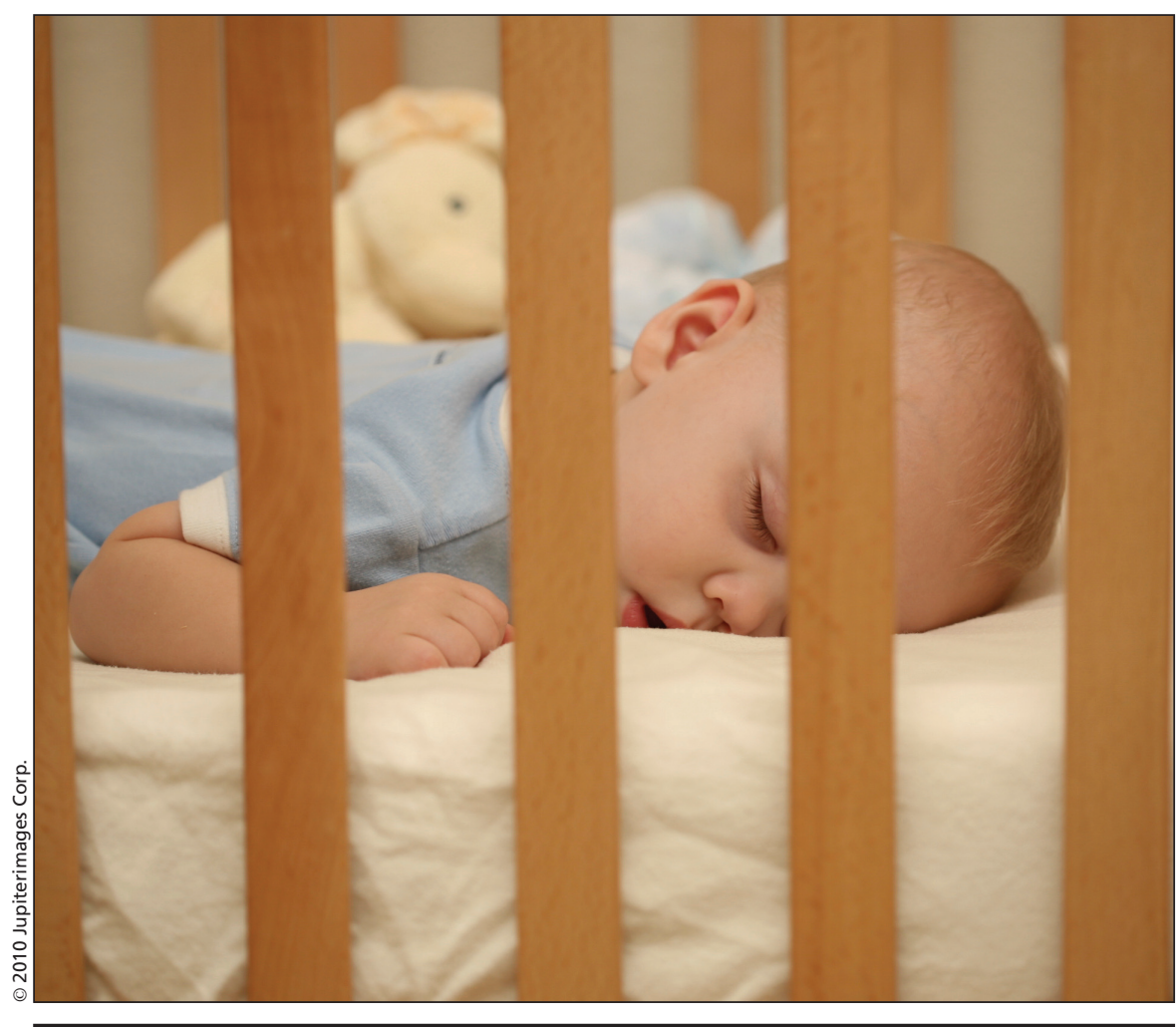

Proposed new consumer safety legislation gives Health Canada mandatory recall powers on products deemed dangerous, such as the baby cribs with an adjustable side that a company recently withdrew from the market.

"Any delay means a greater risk of injury to Canadians, or worse," Aglukkaq told reporters. "As health minister, the amendments made by (Liberal Leader) Michael Ignatieff's Liberal senators disappoint me, and as a mother, their intent disturbs me."

Aglukkaq suggested the Liberal senators - none of whom were appointed by Ignatieff - were responding to pressure from the toy industry, which has been battered in recent years by recalls of toys containing lead.

"Survey results have shown that Canadian parents believe that if a toy or product is available on the market, it is safe," Safe Kids Canada Executive Director Pamela Fuselli told the news conference. "Unfortunately, this is not always the case."

Day countered that his concerns stem from the poorly crafted legisla- tion, which he believes could be challenged under the Charter of Rights and Freedoms. "There are things in this bill that really surprise me in terms of legal drafting."

One proposed amendment would have had the health minister, rather than departmental officials, issue mandatory recalls once the department had discussed any potential risk with a company involved in manufacturing or importing the product in question. Currently, department officials discuss safety problems with the manufacturer or importer, and those discussions could result in a voluntary recall by the company.

Other amendments would have required Health Canada inspectors to get warrants before entering company offices or premises that are not private residence. Currently, the legislation 
does not require inspectors to obtain a warrant before searching an office or the premises of a company whose products they are inspecting, unless it is a private home.

Inspectors need these enhanced powers, says Paul Glover, assistant deputy minister of Health Canada's
Healthy Environment and Consumer Safety branch, because otherwise companies could refuse them entry and destroy documents while the inspector obtains a warrant.

Glover conceded, though, that inspectors could avoid that problem by obtaining a warrant in advance. But doing so "creates a sea of bureaucracy, not just for us but for the courts," he says, adding that Agriculture Canada has no such requirement before entering a premise to perform routine inspections. — Laura Eggertson, Ottawa, Ont.

DOI:10.1503/cmaj.109-3131 